\title{
Listado y resúmenes de Tesis de Licenciatura de la Facultad de Filosofía y Letras de la UBA
}

\section{Compilado por Débora M. Kligmann}

\section{$2018^{*}$}

» Estudio geoarqueológico de palimpsestos en las dunas de la localidad Sayape (San Luis, Argentina).

Por Daniela Storchi Lobos

» La arqueología y la conservación sobre la cerámica arqueológica. Comparación de teorías y metodologías adoptadas en Argentina durante los siglos XX y XXI.

Por Luciana Sosa

» Legislación patrimonial en Argentina desde sus inicios hasta el Siglo XXI. Estudio comparativo del Pukara de Tilcara y el Pukara de La Cueva. Departamento de Humahuaca. Provincia de Jujuy.

Por Daniela Julia Sanz

» Los objetos metálicos de Falda del Cerro: una aproximación a la metalurgia de los primeros siglos D.C. en el sur Calchaquí.

Por Marianela Taboada

» Estrategias de explotación de moluscos durante el Holoceno tardío en la localidad Haskaiam, Moat, sur de Tierra del Fuego.

Por Suray Ayelén Pérez

» Análisis de restos óseos humanos con alteración térmica procedentes del sitio Chenque I (Parque Nacional Lihué Calel, Provincia de La Pampa).

Por Eliana Noelia Lucero

» El hábito de tallar el paisaje verde. Tecnología lítica en el sector septentrional de El Alto-Ancasti (Catamarca).

Por Ignacio Javier Gerola

» Tecnología lítica y petroglifos en Barrancas, Jujuy.

Por Patricio Kohan

» Anclaje en el espacio: un estudio sobre anclas recontextualizadas en la franja costera bonaerense.

Por Julieta Frère

A continuación se incluyen cinco resúmenes de tesis entregados por sus respectivos autores 